\title{
SABAB AL-NUZUL DAN ASAS BERLAKU SURUT DALAM HUKUM PIDANA
}

\author{
Makinuddin \\ Universitas Islam Negeri Sunan Ampel, Jl. A Yani I 17 Surabaya | \\ makinuddin@uinsby.ac.id
}

\begin{abstract}
A/-Qur'an is revealed by Allah as a guidance for mankind. Most of its verses were revealed without circumstantial events on which the verses were revealed. Meanwhile, there are also some of its verses which were revealed to answer or respond particular events or questions that can be easily understood from their historicity especially those which related to Islamic law. This particular events or questions are called sabab al-nuzul (context of revelation) in the study of Qurán. This research shows that there are many advantages of the context of the revelation associated with the legal verses. The wisdom and secret of the verses become the basis of the law promulgation to reach a public interest. As for the impact of the context of the revelation is that the derived law will be enforced since the legal event happened, and not since it was revealed. This rule is based on the principle of "the derivation of Islamic constitution is understood from the particular context of the revelation and not based on the general meaning of the word", particularlyassociated with the criminal act which violatespublic or general interest. Thus, it is clear that the principle of legality is not always enforced in the Islamic criminal law. Under a certain condition, it may be applied retroactively if the criminal actdisturbs public interest. So that, this research will focus on the legal consequences of verses of al-Qur'an which have the historical background and those which do not.
\end{abstract}

Keywords: Reason of the revelation, certain historical background, retroactive, and muharabah

Abstrak: Al-Qur'an diturunkan ada yang tidak melalui sebab dan ini lebih banyak daripada yang melalui sebab dan ia merupakan wahyu yang menjadi petunjuk Allah bagi umat manusia (hudan li al-nas). Sementara itu, ada juga yang melalui sabab al-nuzul, karena adanya fatrat min al-rasul (kekosongan umat manusia dari keberadaan Nabi 
dan Rasul) dan mengandung beberapa hikmah yang dalam, terutama terkait dengan pemahaman ayat-ayat hukum dalam al-Qur'an. Melalui tulisan ini, ditemukan bahwa banyak manfaat sabab al-nuzul terkait dengan ayat hukum, di antaranya dapat diketahui hikmah dan rahasia diundangkannya suatu hukum dan perhatian shara' terhadap kepentingan umum. Dampak sabab al-nuzul dengan penerapan asas berlaku surut (athar raj'), yaitu hukum yang diturunkan akan diberlakukan sejak peristiwa hukum (tindak pidana) itu terjadi, bukan sejak al-Qur'an diturunkan, menurut kaidah sabab al-nuzul, al-'ibrah bi khusus al-sabab, bukan al-'ibrah bi 'umum al-lafz, terkait dengan tindak pidana yang mengganggu masyarakat atau kepentingan umum. Sehingga, menjadi jelas bahwa asas legalitas tidak selamanya diberlakukan dalam hukum pidana Islam maupun positif. Dalam kondisi tertentu dapat diberlakukan surut jika tindak pidana mengganggu kepentingan umum dan menguntungkan pelaku pidana jika terjadi perubahan peraturan dengan menganalogkan kepada peristiwa terdahulu melalui pendekatan sabab al-nuzul, bahkan dalam hukum pidana Islam lebih luas penerapan asas berlaku surut.

Kata Kunci: Sabab al-nuzul, khusus al-sabab, berlaku surut, muharabah.

\section{Pendahuluan}

Al-Qur'an sebagai kitab samawi, yang diturunkan kepada nabi Muhammad SAW., nabi terakhir, yang shari'atnya tidak hanya untuk ummat tertentu dan terbatas berlakunya. Ia merupakan salah satu mukjizat nabi Muhammad SAW. yang terbesar dan tidak habis ditelan masa, berbeda dengan mukjizat nabi sebelumnya, yang hanya dapat dilihat dan dirasakan oleh ummat sewaktu mukjizat itu muncul pada diri nabi (mukjizat hissiyah), seperti nabi Musa AS (laut terbelah dengan lemparan tongkatnya), nabi Ibrahim AS (tidak terbakar api), dan nabi 'Isa as (menghidupkan orang yang meninggal dunia). Karena itu, mukjizat al-Qur'an tergolong mukjizat ma'nawiyah (bersifat abstrak), yang tidak pernah habis diteliti orang sejak nabi masih hidup hingga sekarang dengan berbagai macam tinjauan sesuai dengan disiplin para ilmuan dan peneliti. 
Al-Qur'an diturunkan ada yang melalui sebab dan ada juga yang tidak melalui sebab. Sementara itu, al-Qur'an yang diturunkan tidak melalui sebab lebih banyak daripada yang melalui sebab. Ayat-ayat yang diturunkan tidak melalui sabab alnuzul, karena al-Qur'an merupakan wahyu yang menjadi hidayah Allah bagi ummat manusia. Adanya, dua model tentang turunnya al-Qur'an tersebut pasti mengandung hikmah tersendiri, lebihlebih yang terkait dengan ayat hukum walaupun al-Qur'an itu sendiri sejak awal diturunkan Allah SWT. secara sekaligus (daf'ah wahidah) dari al-lawh al-mahfuz (tempat yang sangat terjaga) ke Langit Dunia (bayt al-'izzah) pada bulan Ramadlan, yang dikenal dengan sebutan laylat al-qadr. Kemudian berikutnya, al-Qur'an diturunkan kepada nabi Muhammad SAW secara berangsurangsur, selama lebih kurang 23 (dua puluh) tiga tahun, 10 tahun di Makkah dan 13 tahun di Madinah.

Secara umum, yang melatar belakangi turunnya al-Qur'an, berarti diutusnya nabi Muhammad SAW. adalah karena adanya fatrat min al-rasul (kekosongan umat manusia dari keberadaan Nabi dan Rasul), sebagaimana termaktub dalam surat al-Maidah (4): 19. Untuk itu, melalui pengetahuan sabab al-nuzul, umat manusia dapat lebih mudah dan tepat dalam memahami ayat-ayat al-Qur'an dan dapat menyelesaikan permasalahan yang ada sekarang dengan membandingkannya pada peristiwa sewaktu alQur'an diturunkan.

Jika diperhatikan secara seksama tentang sabab al-nuzul, maka diketemukan bahwa turunnya al-Qur'an merupakan jawaban dari suatu peristiwa yang membutuhkan jawaban sebagai alat penyelesaian perkara, terutama terkait dengan ayat hukum. Untuk itu, masalah yang ada pada tulisan ini terkait dengan (1) Bagaimana manfaat sabab al-nuzul terkait dengan ayat hukum? dan (2) Bagaimana dampak sabab al-nuzul terhadap penerapan asas berlaku surut? 


\section{Pengertian Sabab al-Nuzul}

Ali al-Sabuni dalam kitabnya, al-Tibyan fi 'Ulum al-Qur'an, menjelaskan bahwa sabab al-nuzul ialah suatu peristiwa yang menyebabkan ditunkannya ayat terkait dengan suatu peristiwa dan kejadian tersebut, baik yang berupa pertanyaan yang diajukan kepada nabi Muhammad SAW atau kejadian yang berkaitan dengan urusan agama. ${ }^{1}$ Sementara itu, Manna' al-Qattan mengartikannya dengan sesuatu yang menyebabkan diturunkannya al-Qur'an dengan waktu peristiwa itu terjadi, baik berupa suatu peristiwa atau pertanyaan yang diajukan. ${ }^{2}$ Dalam hal ini, sabab al-nuzul merupakan suatu peristiwa yang menjadi sebab turunnya ayat, baik sebagai tanggapan atas peristiwa yang umum atau khusus, sebagai jawaban terhadap pertanyaan kepada nabi Muhammad SAW., sebagai jawaban dari pertanyaan nabi Muhammad SAW. maupun sebagai tanggapan atas pertanyaan atas pertanyaan yang bersifat umum. ${ }^{3}$

\section{Bentuk sabab al-nuzul ayat al-Qur'an}

Bentuk-bentuk sebab turunnya al-Qur' an terdiri atas:

1. Sabab al-nuzul yang berbentuk peristiwa, yang meliputi (a) pertengkaran, seperti yang bercamuk antara kabilah Aws dan Khazraj, yang ditimbulkan dari intrik-intrik orang-orang Yahudi, sehingga mereka berteriak, senjata-senjata, kemudian turunlah surat Ali ‘Imran (3): 100; (b) kesalahan serius, seperti peristiwa seorang yang menjadi imam shalat dan mabuk, sehingga salah membaca surat al-Kafirun, dalam hal ini 'Ali bin Abi Talib sewaktu diundang oleh Abd al-Rahman bin 'Awf untuk menikmatai jamuan makanan dan kemudian dia menjadi imam shalat dan keliru membaca surat al-Kafirun dengan lafal "la a'budu ma ta'budun" yang seharusnya dibaca

' Muhammad Ali al-Sabuni, al-Tibyan fi 'Ulum al-Qur'an, (Damaskus: Maktabat al-Ghazali, 1390 H), 22.

2 Manna' al-Qattan, Mabahith fi 'Ulum al-Qur'an, (Beirut: Dar al-Qalam li al-Malayin, 1988), I32.

${ }^{3}$ M. Quraish Shihab et.al, Sejarah dan Ulumul Qur'an, (Jakarta: Pustaka Firdaus, 1999), 83-86. 
"a'budu ma ta'budun", kemudian turunlah surat al-Nisa' (4): 43 (Ya ayyuha al-ladhina amanu la taqrabu al-salah wa antum sukara...) dan (c) berupa cita-cita dan keinginan, seperti persesuaian cita-cita Umar bin Khattab dengan ketentuan yang ada pada al-Qur'an. Misalnya, ketika Rasulullah SAW. sedang tawaf, Umar berkata kepadanya': Ini adalah maqam (tempat shalat) nenek moyang kita (Ibrahim)? Beliau menjawabnya, itu benar. Umar berkata lagi, apakah sebaiknya tempat ini dijadikan tempat shalat? Kemudian turunlah surat al-Baqarah (2): 125.

2. Sabab al-nuzul dalam bentuk pertanyaan, yang terdiri atas (a) pertanyaan yang berhubungan dengan sesuatu yang terjadi pada masa lampau, sebagaimana firman Alam dalam surat alKahfi (18): 83 (wa yasalunak 'an dhi al-qarnayn); (b) pertanyaan yang berhubungan dengan sesuatu yang sedang berlangsung pada masa itu, sebagaimana firman Allah dalam surat al-Isra' (17): 85 (yasalunaka 'an al-ruh..); (c) pertanyaan yang berhubungan dengan sesuatu yang terjadi di masa mendatang, sebagaimana firman Allah dalam surat al-Nazi'at (79): 42 (wa yasalunaka 'an al-sa'ah ayyana mursaha). ${ }^{4}$

Fungsi memahami sabab al-nuzul, yaitu:

1. Mengetahui hikmah dan rahasia diundangkannya suatu hukum dan perhatian shara' terhadap kepentingan umum, tanpa membedakan etnik, jenis kelamin, dan agama. Misalnya, turunnya ayat terkait pengahapusan minuman keras selama 4 kali tahapan, yaitu al-Nahl (16): 67, al-Baqarah (2): 219, al-Nisa' (4): 43 dan al-Maidah (5): 90-91;

2. Mengetahui sabab al-nuzul dapat membantu memberikan kejelasan terhadap beberapa ayat. Misalnya, 'Urwah bin Zubayr mengalami kesulitan dalam memahami hukum fard

\footnotetext{
${ }^{4}$ Ahmad Syadali dan Ahmad Rofi'i, Ulumul Quran, vol. I, (Bandung: Pustaka Setia, 1997), 90-91.
}

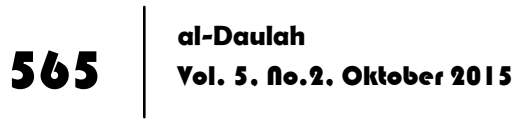


sa'iy antara Safa dan Marwah, sebagiamana surat al-Baqarah (2): 158;

3. Pengetahuan sabab al-nuzul dapat mengkhususkan hukum terbatas pada lafal umum, terutama ulama yang menggunakan kaidah khusus al-sabab, bukan 'umum al-lafzi. Misalnya, ayat zihar pada permulaan surat al-Mujadalah, yaitu dalam kasus Aws bin al- Samit yang menzihar istrinya, Khawlah binti Hakam bin Tha'labah. Hukum yang terkandung di dalamnya dikhususkan bagi keduanya, bukan lainnya;

4. Sabab al-nuzul dapat membantu memahami apakah suatu ayat berlaku umum atau berlaku khusus, kemudian dalam hal apa ayat itu diterapkan. Artinya, maksud yang sesungguhnya suatu ayat dapat dipahami melalui pengenalan sabab al-nuzuls;

5. Pengetahuan sabab al-nuzul akan mempermudah orang menghafal ayat-ayat al-Qur'an serta memperkuat keberadaan wahyu dalam ingatan orang yang mendengarnya jika mengetahui sebab turunnya. Hal ini, karena keterkaitan sebab dan musabbab (akibat), hukum dan peristiwnya, peristiwaelaku, masa dan tempatnya, semua ini merupakan faktor-faktor yang menyebabkan kemantapan dan terlukisnya sesuatu ingatan. ${ }^{6}$

\section{Asas-asas Perundang-undangan Hukum Positif}

Fuller mengajukan suatu pendapat untuk mengukur apakah kita pada suatu saat dapat berbicara mengenai adanya suatu sistem hukum. Ukuran tersebut diletakkan dalam delapan asas yang disebut Principles of legality, yaitu (1) Suatu sistem hukum harus mengandung peraturan-peraturan, yang tidak hanya mengandung keputusan-keputusan yang bersifat ad hoc (untuk urusan tertentu saja); (2) Peraturan-peraturan yang telah dibuat

${ }^{5}$ M. Quraish Shihab, Membumikan al-Qur'an, (Bandung: Mizan, 1992), 29; M. Quraish Shihab et.al, Sejarah, 78-8I

${ }^{6}$ Syadali, Ulumul Qur'an, 132. 
harus diumumkan; (3) Tidak boleh ada peraturan yang berlaku surut; (4) Peraturan-peraturan harus disusun dalam bahasa yang mudah dimengerti; (5) Suatu sistem tidak boleh mengandung peraturan-peraturan yang bertentangan satu sama lain; (6) Peraturan-peraturan tidak boleh mengadung tuntutan yang melebihi apa yang dapat dilakukan; (7) Tidak boleh ada kebiasaan untuk sering merubah-rubah kecocokan antara pereturanperaturan yang diundangkan dengan pelaksanaan sehari-hari. ${ }^{7}$

Sementara itu, Pipin menjelaskan bahwa asas-asas perundang-undangan terdir atas, yaitu (1) Undang-undang tidak berlaku surut; (2) Undang-undang yang berlaku kemudian membatalkan undang-undang yang terdahulu; (3) Undangundang yang dibuat oleh penguasa yang lebih tinggi mempunyai kedudukan yang lebih tinggi pula; (4) Undang-undang yang bersifat khusus mengenyampingkan undang-undang yang bersifat umum; (5) Undang-undang tidak dapat diganggu gugat; (6) Undang-undang sebagai sarana untuk memaksimal mungkin dapat mencapai kesejahteraan spiritual bagi masyarakat maupun individu, melalui pembaharuan atau pelestarian (asas welfaarstaat). ${ }^{8}$ Sedangkan, pentingnya asas hukum (1) bagi pengundang-undang, yaitu member garis-garis besarnya dalam pembentukan hukum; (2) bagi hakim, yaitu member bahan yang sangat berguna dam penafsiran undang-undang secara dogmatis serta dalam melakukan undang-undang secara analogis; dan (3) bagi ilmu hukum, yaitu asas merupakan hasil peningkatan berbagai peraturan hukum dati tingkatan yang paling rendah. ${ }^{9}$

Asas hukum yang melekat pada hukum pidana yaitu (1) Asas nonrekroaktif, yang dalam KUHP secara eksplisit tersirat dalam Pasal 1 ayat (1) Asas pembuktian terbalik, misalnya seorang koruptor harus membuktikan, bahwa semua hartanya bukan hasil

\footnotetext{
${ }^{7}$ Mudjiono, Sistem Hukum dan Tata Hukum Indonesia, (Yogyakarta: Liberty, 2000), 3; Burhan Ashshafa, Metode Penelitian Hukum, (Jakarta: PT Makasaty, 200 I), 6.

${ }^{8}$ Pipin Syarifin, Pengantar IImu Hukum, (Bandung: CV Pustaka Setia, 1999), I 46.

${ }^{9}$ Mudjiono, Sistem Hukum, 4.
} 
korupsi hartanya bukan hasil korupsi, maka dia dapat dbebakan; (3) Asas praduka tak bersalah, yang berguna untuk melindungi hak asasi manusia dan nama baik seseorang. Melalui asas ini, bahwa seseorang yang tersangkut hukum sebelum diputus oleh hakim, maka orang tersebut tetap dinyatakan "benar" dan harus dihormati; (4) Asas legalitas, yang bermakna bahwa seseorang tidak dikenai hukuman jika belum ada peraturan yang mengatur. ${ }^{10}$

Asas hukum pidana Islam, yaitu (1) tidak berlaku surut, yang berarti asas legalitas; (2) asas tak bersalah, bahkan lebih dahulu daripada asas dalam hukum positif; (3) tidak sahnya hukuman karena ada unsur shubhah (kesamaran). ${ }^{11}$ Hakikatnya, asas hukum pidana dalam hukum positif terdapat dalam hukum pidana Islam, bahkan lebih dahulu, termasuk pembuktian terbalik, sebagaimana dalam hadis "al-bayyinah 'ala al-muddai' wa al-yamin 'ala man ankara".

\section{Hukuman dalam Jarimah Hudud}

Dalam hukum pidana Islam, 'uqubah (hukuman) terbagi menjadi menjadi tiga macam, yaitu hukman had, qisas/diyah, dan ta'zir, yang masing-masing mempunyai cir-ciri tersendiri, yang berbeda dengan hukum positif.

Menurut pengertian bahasa, had bermakna larangan (man'u), sedangkan dalam pengertian shara' bermakna suatu hukuman yang ditetapkan melalui nas al-Qur'an atau hadis terkait sengan tindak pidana (jarimah), yang di dalam terjadi pelanggaran hak Allah. Makna pengertian tersebut menunjukkan bahwa hak itu ada empat, yaitu (1) Hak yang murni bagi Allah; (2) Hak yang murni bagi hamba, seperti hak kepemilikan seorang hamba, hak mengambil manfaat bagi pemilik; (3) Hak Allah lebih dominan, seperti had menurut sebagian imam, misalnya had qadhaf; (4) Hak hamba lebih dominan, seperti hak qisas.

${ }^{10}$ Zainal Asikin, Pengantar IImu Hukum, (Jakarta: Raja Grafindo Persada, 20 I2), I03- 05.

" Makhrus Munajat, Dekonstruksi Hukum Pidana Islam, (Sleman: Logung Pustaka, 2004), 29-34. 
Hak Allah juga dapat dimaknai dengan hak mujtama' (masyarakat), karena Allah tidak sekali-kali memerintah sesuatu atau melarang sesuatu, kecuali untuk mewujudkan masyarakat yang utama, yang kelihatan keunggulannya dan tertutupi kerendahannya. Sementara itu, masyarakat yang unggul selalu menetapkan keharusan untuk menjaga keturunan atau keluarga. Ulama fiqh menetapkan, setiap sesuatu yang hak Allah-nya lebih unggul, maka tidak perlu memperhatikan pemeliharaan yang terkait dengn kemaslahatan perorangan, tetapi yang diperhatikan pemeliharaan kemaslahatan masyarakat, semantara maslahah individu bersifat mengikuti $\left(\right.$ taba $\left.{ }^{\prime}\right) .{ }^{12} \mathrm{Di}$ antara jarimah hudud adalah jarimah qadhaf dan hirabah, yang berlakunya menggunakan asas berlaku surut sewaktu diturunkannya ayat al-Qur'an.

\section{Asas Legalitas dalam Hukum Pidana}

Asas Nullum delictum nulla poena sine prae via lege poenale berasal dari van Feuerbach, sarjana hukum pidana Jerman (17751833). Dengan asas ini, orang yang akan melakukan perbuatan pidana yang dilarang tadi telah mengetahui pidana apa yang akan dijatuhkan kepadanya jika nanti dia melakukan perbuatan itu. Dengan demikian, dalam hatinya, dia mengadakan rem atau tekanan untuk tidak melakukannya, Jika dia melakukan perbuatan tadi, hal ini akan diajatuhi pidana kepadanya itu dapat dipandang sebagai hal yang sudah disetujui sendiri. Kalimat nullum delictum... dalam bahasa Latin bemakna tidak ada delik (perbuatan) dan tidak ada pidana (hukuman) tanpa ada peraturan dahulu. Dalam bahasa Belanda dikenal istilah "geen straf zonder schuld", tidak ada pidanna tanpa kesalahan atau dkenal dengan asas legalitas dalam Pasal 1 ayat (1) KUHP (Kitab Undang-undang Hukum Pidana).

Asas legalitas yang termuat dalam Pasal 1 ayat1 KUHP ini mengandung tiga pengertian, yaitu: (1) Tidak ada perbuatan yang

12 Muhammad Abu Zahrah, al-'Uqubah, (Mesir: Dar al-Fikr al-'Arabi, 1999), 63

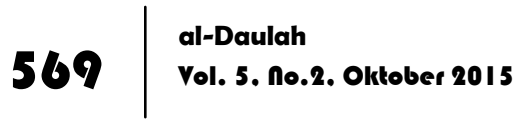


dilarang atau diancam dengan pidana jika hal itu tidak terlebih dahulu dinyatakan dalam suatu aturan undang-undang; (2) Untuk menentukan adanya perbuatan pidana tidak boleh digunakan analogi (qiyas); dan (3) Aturan hukum pidana tidak berlaku surut. Untuk itu, dampak asas nullum delictum, yaitu seorang dapat dihukum jika dia melakukan perbuatan yang oleh hukum dan peraturan telah disebut secara tegas sebagai suatu pelanggaran ketertiban umum. Dengan demikian, kemungkinan seorang melakukan suatu perbuatan yang pada hakikatnya nerupakan suatu kejahatan, tetapi karena tidak disebutkan oleh hukum sebagai sebagai suatu pelanggaran ketertiban umum, dia menjadi tidak terhukum. Selanjutnya, Pasal 1 ayat (2) KUHP dinyatakan, Jika ada perubahan dalam perundang-undangan sesudah saat melakukan perbuatan, maka digunakan aturan yang paling ringan bagi terdakwa. Sementara itu, Pasal 14 ayat 3 UUDS Tahun 1950 dinyatakan juga, jika ada perubahan dalam aturan hukum seperti tersebut dalam ayat di atas, maka dipakailah ketentuan yang lebih baik bagi si tersangka. ${ }^{13}$

\section{Asas Retroaktif dalam Hukum Pidana}

Salah satu asas undang-undang adalah asas tidak berlaku surut (retroaktif). Hal ini sesuai dengan pasal 2 Algamene Bepalingen Van Wetgeving (AB), yang berbunyi "De wet verbindt alleen voor het toe komende en heft gene terug werkene," undangundang itu hanya mengikat bagi masa yang akan datang dan tidak mempunyai kekuatan berlaku surut. Dalam hal ini dapat dilihat pasal 1 ayat (1) KUHP di Indonesia. Pasal ini memuat asas yang terkenal dengan "Nullum delictum noella sine praevia lege poenale," tiada suatu perbuatan dapat dipidana kecuali berdasarkan ketentuan perundang-undangan pidana yang telah ada. Asas ini

13 Pipin Syaripin, Hukum Pidana di Indonesia, (Bandung: Pustaka Setia, 2000), 27- 28; Tongat, Dasar-dasar Hukum Pidana Indonesia dalam Prespektif Pembaharuan, (Malang: UMM Press, 2008), 51 
dikenal dengan sebutan asas legalitas, yang berasal dari adagium Anselm Von Feuerbach. ${ }^{14}$

Pasal 1 ayat (1) KUHP secara tegas tidak menerima asas tidak berlaku surut. Artinya, undang-undang ini tidak dapat diterapkan terhadap suatu perbuatan (pidana) yang terjadi setelah undangundang ini diberlakukan. Akan tetapi, larangan berlaku surutnya aturan pidana itu ada pengecualiannya. Artinya, dalam hal-hal tertentu, aturan pidana boleh berlaku surut, yaitu sewaktu terjadi perubahan undang-undang yang menguntungkan pelaku setelah perbuatan itu dilakukan, sebagaimana diatur secara tegas dalam Pasal 1 (2) KUHP. Jika sesudah perbuatan dilakukan ada perubahan dalam perundang-undangan, dipakai aturan yang paling ringan bagi terdakwa. ${ }^{15}$

Asas hukum pidana Islam adalah asas legalitas, bukan retroaktif (berlaku surut). Asas ini berupa kaidah-kaidah yang dipetik dari kandungan al-Qur'an, yaitu: (1) la jarimah wa la 'uqubah illa bi al-nas, (tidak ada tindak pidana dan tidak ada hukuman kecuali berdasarkan peraturan yang telah ada); (2) la hukm li af'al al-'uqala' qabl wurud al-nas (tidak ada hukum bagi perbuatan orangorang yang berakal sehat sebelum ada suatu peraturan); dan (3) alasl fi al-ashya' wa al-af'al al-Ibahah, (pada dasarnya semua perkara dan perbuatan adalah boleh). ${ }^{16}$ Sementara itu, kaidah-kaidah tersebut didasarkan pada nas-nas yang jelas dan khusus, yaitu: (1) surat al-Isra' (17): 15 (...Dan Kami tidak akan mengadzab sebelum Kami mengutus seorang Rasul);17(2) surat al-Qasas (28): 59 (Dan Tuhanmu tidak membinasakan kota-kota sebelum Dia mengutus di ibukota itu seorang Rasul yang membacakan ayat-ayat kami

\footnotetext{
${ }^{14}$ Hartono Hadisoeprapto, Pengantar Tata Hukum Indonesia, (Yogyakarta: Libery, 2000), 25; Andi hamzah, Kampus Hukum, (Jakarta: Ghallia Indonesia, Cet. I, 1986), 347; R. Susilo, Kitab Undang-Undang Hukum Pidana (KUHP) Serta Komentar-Komentar Lengkap Pasal-Pasal, (Bogor: Politeia: 1976), 23

15 Tongat, Dasar-dasar.., 67

${ }^{16}$ Abd al-Qadir Awdah, al-Tashri' al-Jinal al-Islami Muwazanah bi al-Qanun al-Wad'i, Vol. I (Beirut: Dar al-Kutub al-'Arabi , t.t.), II5- 117

${ }^{17}$ Depag, Al-Quran dan Terjemahnya, (Jakarta: Proyek Pengadaan Kitab Suci al-Quran, 1983), 426
} 
kepada mereka dan tidak pernah (pula) Kami membinasakan kotakota kecuali penduduknya melakukan kezaliman);18 dan (3) surat al-Shu'ara' (28): 208 (Dan Kami tidak membinasakan suatu negeripun, melainkan sesudah ada baginya orang-orang yang memberi peringatan). ${ }^{19}$

Dalam kitab-kitab fiqh, pembahasan asas retroaktif (berlaku surut) tidak dituangkan secara khusus. Akan tetapi jika ditelusuri secara seksama tentang ayat-ayat al-Quran dan sebab-sebab turunnya, maka ternyata diketemukan asas retroaktif (asar raj'i), yaitu dalam masalah hirabah, qazaf dan zihar. Artinya: hukuman ketiga tindak pidana tersebut diterapkan untuk tindak pidana (jarimah) sebelum turunnya al-Quran. Dengan demikian, sebenarnya hukum pidana Islam tidak mengenal retroaktif, tetapi asas legalitas, kecuali dalam dua hal, yaitu: (1) tindak pidana yang berbahaya, yang mengganggu keamanan dan ketertiban umum, dan (2) jika hukuman itu menguntungkan bagi pelaku. Sedangkan, perbedaan antara dua perkecualian tersebut adalah (1) tindak pidana yang berbahaya dan mengganggu keamanan serta ketertiban umum adalah bersifat fakultatif (boleh) bagi shari'. Artinya: shari' boleh menerapkan asas berlaku surut (athar raj'i) jika mendatangkan kemaslahatan; dan (2) tindak pidana yang hukumannya menguntungkan pihak pelaku adalah bersifat imperatif (wajib)..$^{20}$

Asas retroaktif dalam Islam telah dikenal sejak al-Qur'an diturunkan kepada nabi Muhammad SAW. dalam hal-hal tertentu seperti hirabah, qazaf dan zihar. Artinya, pada prinsipnya dalam Islam tetap menjunjung asas legalitas berdasarkan atas yang jelas dan khusus. Hal ini berbeda dengan hukum wad'i (buatan manusia). Dalam hal ini, sebelum revolusi Perancis akhir abad 18,

\footnotetext{
${ }^{18} \mathrm{lbid} ., 619$

${ }^{19} \mathrm{lbid} ., 588$

${ }^{20}$ Awdah, al-Tasyri, 262-267; Sa'id Hawwa, al-Islam, Vol. 4, (Beirut: Dar al-Qalam, t.t), 567; Muhammad Salim al-'Awwa, Fi Usul al-Nizam al-Jinai al-Islami, (Kairo: Dar al-Ma'arif, 1979), $56-61$.
} 
asas berlaku surut diberlakukan. Akan tetapi, setelah itu diberlakukan asas legalitas, yang kemudian dimasukkan dalam pernyataan hak-hak manusia, yang dikeluarkan pada tahun 1789 M, yang kemudian asas ini diambil oleh Negara lain. ${ }^{21}$

Dengan demikian, pemberlakuan asas retroaktif dalam hukum positif adalah mengikuti teori-teori hukum Islam, yakni dibatasi hanya dalam hal-hal yang berupa tindak pidana yang berbahaya bagi kepentingan umum, yang dalam hal ini kepentingan perorangan dikalahkan oleh kepentingan umum.

\section{Sabab al-Nuzul dan Berlaku Surut}

Dalam al-Qur'an terdapat ayat yang berlakunya menggunakan asas berlaku surut (athar raj'i) berdasarkan teori sabab al-nuzul, yaitu jarimah qadhaf (tuduhan zina kepada orang lain), hirabah (pembegalan/penyamun), dan zihar (sumpah zihar). Qadhaf dan hirabah tergolong dalam hukum pidana, sedangkan zihar tergolong dalam hukum perdata (hukum keluarga) walaupun di dalamnya ada unsur pidananya. Artinya, ayat-ayat al-Qur'an yang diturunkan melalui sabab al-nuzul, selain 3 ayat tersebut, diberlakukan asas legalitas.

\section{Sabab al-Nuzul dan Jarimah Qadhaf}

Sesudah pererangan dengan Bani Mustaliq, yang terjadi pada bulan Sha'ban, tahun kelima Hijrah, yang diikuti oleh orang-orang munafik dan isteri nabi, 'Aishah binti Abu Bakar, sesuai hasil undian yang diadakan oleh isteri-isteri nabi Muhammad SAW.. Dalam perjalanan, mereka berhenti pada suatu tempat, kemudian 'Aishah keluar sebentar untuk suatu keperluan, kemudian kembali ke tempat peristirahatan, tiba-tiba merasa kalungnya hilang. Akhirnya, dia pergi lagi untuk mencari kalungnya yang hilang. Sementara, rombongan perang itu berangkat dengan penuh persangkaan, bahwa 'Aishah masih diredup tempat peristirahatan.

${ }^{21}$ A. Hanafi, Asas-Asas Hukum Pidana Islam, (Jakarta: Bulan Bintang, Cet: II, 1976), 74.

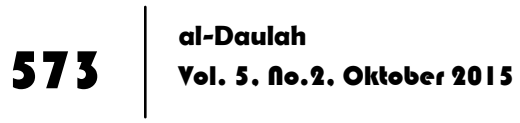


Kemudian, setelah kembalinya 'Aishah dari mencari kalungnya ternyata redup sudah kosong dan rombongan telah berangkat. Pasa saat itu, 'Aishah duduk dengan harapan rombongan akan kembali menjemputnya. Dalam waktu tidak lama kemudian, lewatlah shahabat nabi, Sofwan Ibn Mu'attal dan menemukan seorang perempuan yang sedang tidur sendirian. Dia terkejut dengan di depan itu isteri Nabi Muhammad SAW. ('Aishah). Lantas 'Aishah bangun, lalu dia dipersilahkan untuk menaiki untanya dan Sofwan bin al-Mu'attil al-Sulami berjalan di depannya sambil menuntun untanya sampai ke Madinah. ${ }^{22}$

Setelah kejadian tersebut, akhirnya orang-orang yang melihat 'Aishah dengan Sofwan membicarakan menurut pendapatnya sendiri-sendiri. Dalam hal ini, mulailah terjadi desas desus dan orang-orang munafik membesar-besarkan peristiwa tersebut, sehingga fitnah yang mengarah kepada 'Aishah tersebar luas sampai menimbulkan kegoncangan yang besar di lingkungan ummat Islam. Bahkan, dalam sejarah, peristiwa tersebut sempat menimbulkan peperangan antara Kabilah Aws dan Khazraj. Akibat yang ditimbulkan dari jarimah ini sangat berbahaya dan mengganggu keutuhan orang-orang Islam pada saat itu. Kemudian setelah turun surat al-Nur (24): 4, Rasulullah SAW. menghukum pelaku fitnah dengan hukuman cambuk sebanyak 80 kali cambukan. Dengan demikian, surat al-Nur (24): 4 tersebut diberlakukan surut dengan pertimbangan (alasan sosiologis) demi ketenangan diri korban dan mengembalikan nama baik mereka serta menghapuskan kesan jelek dari masyarakat umum²3, lebihlebih terkait dengan 'Aishah bint Abi Bakar, istri Rasulullah SAW, yang dikenal sebagai ummahat al-mu'minin.

Hukuman terhadap pelaku jarimah qadhaf (menuduh orang laki-laki atau perempuan dengan tuduhan zina denga tanpa ada

\footnotetext{
22 Ibn Kathir, Tafsir al-Qur'an al-'Azim, Vol. 3, (Mesir: 'Isa al-Babi al-Halibi, t.t), 268-269.

${ }^{23}$ Abd al-Qadir Awdah, al-Tashri, vol. I, I53. Adapun orang yang dikenai hukuman tersebut, yaitu dua orang laki-laki (Hassan dan Mistah) dan satu orang perempuan, yaitu Hamnah. alSayyid Sabiq, Fiqh al-Sunnah, vol. 2, (Beirut: Dar al-Fikr, 1977), 373,
} 
dalil atau bukti) adalah demi menjaga masyarakat (himayat almujtama') dari mafsadah (kerusakan) yang empat:24

1. Kerusakan tersebarnya suatu kejelekan (fahishah). Artinya, jika masyarakat menuduh orang lain berbuat fahishah, tanpa ada alasan pembenar, maka akan tersebar perkataan tentang hal ini dengan tanpa ada penjelasan. Dalam hal ini akan menimbulkan kerusakan pada masyarakat, karena tersebarnya ucapan tersebut mudah dilakukan, sebagaimana firman Allah dalam surat al-Nur (24): 15 (Sesungguhnya orang-orang yang ingin agar (berita) perbuatan yang Amat keji itu tersiar di kalangan orang-orang yang beriman, bagi mereka azab yang pedih di dunia dan di akhirat. dan Allah mengetahui, sedangkan, kamu tidak mengetahui).

2. Kerusakan atas tuduhan kepada orang yang baik dengan cara yang batil, yakni berbuat zalim kepada mereka, padahal mereka tidak berdasakan ilmu. Karena itu, harus dijaga tersebarnya melalui hukum yang dan bersifat preventif, yang dapat memutus mulu-mulutyang jelek.

3. Merusak sifat malu yang bersifat umum, karena malu itu akan menyebabkab seorang mukmin tidak berkata dengan perkataan yang kotor. Sedangkan, malu itu seluruhnya baik, yakni hubungan masyarakat yang dijadikan sebagai pengikat, yaitu menjaga dari kejelekan.

4. Pada umumnya, orang-orang yang dituduh zina adalah orang yang mempunyai kedudukan tinggi di masyarakat dan hal ini menyebabkan mudahnya jarimah qadhaf ini merasuk pada hatinya orang-orang yang lemah.

Dalam hal ini, jika seorang yang alim, pemimpin yang mempunyai jabatan, atau seseorang yang berkedudukan di kalangan masyarakat, dan tuduhan tersebut dibenarkan atau disebarluaskan oleh masyarakat, maka akan menghilangkan kewibawaan. Oleh karena itu, pelaku yang menuduh zina orang 
lain dikenai sanksi (hukuman), yaitu (1) hukuman badan, didera 80 kali dera, dan (2) hukuman adabiyyah (etika), tidak diterima persaksiannya untuk waktu selama-lamanya. Hal ini, karena orang yang mempermudah hinaan berupa ucapan yang merendahkan adalah tidak perlu dia ditunda untuk mengangkat yang hak atau menghilangkan yang batal melalui persaksiannya, karena memberlakukan ucapan melalui lisannya dengan tanpa penetapan yang benar adalah dapat merusak (mengurangi) kehormatan dan jika kehormatan telah berkurang, maka akan mengurangi kebenaran.

Dalam hal ini, Allah menceritakan tentang tuduhan terhadap 'Aishah binti Abi Bakr melalui berita bohong yang dituduhkan orang-orang munafik dan dia terjaga dari tuduhan tersebut, sebagaimana dalam firman Allah dalam al-Nur (24): 12-17, yang artinya: "Mengapa di waktu kamu mendengar berita bohong itu orangorang mukminin dan mukminat tidak bersangka baik terhadap diri mereka sendiri, dan (mengapa tidak) berkata: "Ini adalah suatu berita bohong yang nyata"(12). Mengapa mereka (yang menuduh itu) tidak mendatangkan empat orang saksi atas berita bohong itu? Olah karena mereka tidak mendatangkan saksi-saksi Maka mereka Itulah pada sisi Allah orang- orang yang dusta (13). Sekiranya tidak ada kurnia Allah dan rahmat-Nya kepada kamu semua di dunia dan di akhirat, niscaya kamu ditimpa azab yang besar, karena pembicaraan kamu tentang berita bohong itu (14). (Ingatlah) di waktu kamu menerima berita bohong itu dari mulut ke mulut dan kamu katakan dengan mulutmu apa yang tidak kamu ketahui sedikit juga, dan kamu menganggapnya suatu yang ringan saja. Padahal Dia pada sisi Allah adalah besar (15). Dan mengapa kamu tidak berkata, diwaktu mendengar berita bohong itu: "Sekali-kali tidaklah pantas bagi kita memperkatakan ini, Maha suci Engkau (ya Tuhan kami), ini adalah Dusta yang besar."(16). Allah memperingatkan kamu agar (jangan) kembali memperbuat yang seperti itu selama-lamanya, jika kamu orang-orang yang beriman (17).

Dengan hal-hal tersebut, Islam menghendaki masyarakat yang bersih dan terjaga, yang keberadaannya hanya tampak 
sesuatu yang baik dan tidak ada seorang pun yang berkata jelek. Kemudian Dia berfirman dalam surat al-Nur (24): 23 yang artinya: "Sesungguhnya orang-orang yang menuduh wanita yang baik-baik, yang lengah lagi beriman (berbuat zina), mereka terkena laknat di dunia dan akhirat, dan bagi mereka azab yang besar."

\section{Sabab al-Nuzul dan Jarimah Hirabah}

Diriwayatkan, bahwa ada serombongan manusia dari 'Uraynah datang ke Madinah, lalu mereka merasa tidak enak badan di Madinah. Kemudian Rasulullah SAW. mengirim mereka ke onta sedekah dan menyuruh mereka air susu dan air kencing onta tersebut. Mereka melakukannya dengan baik, akhirnya mereka sehat. Akan tetapi, kemudian mereka murtad dan membunuh pengembala unta tersebut dan merampasnya. Kemudian, Rasulullah mengirim pasukan untuk mengikuti jejak mereka, kemudian dapat tertangkap, lalu tangan dan kaki mereka dipotong dengan berselang seling, matanya dicocok dengan palu, lantas dilempar ke tempat yang panas sehingga mereka mati. Kemudian turunlah ayat al-Maidah (5): $33 . .^{25}$

Dalam satu riwayat, Rasulullah SAW. memerintahkan dua puluh pemuda Ansar dan salah satunya diangkat menjadi pemburu jejak (Qaif) yang bernma Kurz bin Jabir. Setelah mereka tertangkap di Harrah, kemudian dihadapkan kepada Rasulullah. Kemudian diperintahkan potong tangan dan kaki mereka secara berselang, dicocok mata merekka dengan besi panas, kemudian dibiarkan di terik matahari sampai mati. ${ }^{26}$

${ }^{25}$ Ali al-Sabuni, Rawa'i al-Bayan, vol. I, (Beirut: Dar al-Fikr, t.t), 548. Dalam teks lain tidak 'uraynah, tetapi rombongan 'Ukal yang berjumlah 8 orang dan berbaiat di hadapan nabi Muhammad dan menetap, kemudian mereka terkena sakit kuning atau lever. Ada juga riwayat yang menyatakan empat orang dari 'Uraynah dan 3 orang dari 'Ukal. Semuanya ada kesamaan, bahwa mereka murtad dan mmembunuh serta merampas unta-unta milik orang Islam, sehingga nabi menghukum mereka, kemudian turunlah al-Maidah: 33. Ibnu Kathir, Tafsir alQur'an al-'Azim, 48-49. Kementrian Agama RI, Al-Qur'an dan Tafsirnya, vol. 2, (Jakarta: Sinergi Pustaka Indonesia, 2012), 390

${ }^{26}$ al-Bukhari, Sahih al-Bukhari, vol. IV, (Beirut: Dar al-Fikr, t.t), 5 ।

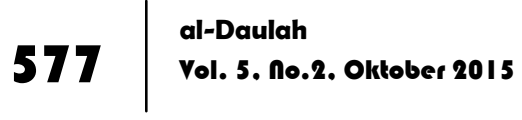


Surat al-Maidah (5); 33 secara tegas menyatakan, bahwa orang-orang yang mengganggu keamanan dan mengacau ketentraman, menghalang-halangi berlakunya hukum, keadilan dan syari'at, merusak kepentingan umum, seperti membinasakan ternak, merusak pertanian dan lain-lain, mereka dapat dibunuh, disalib, dippotong tangan dan kakinya bersilang atau disilangkan. Hukuman pada ayat ini ditetapkan sedemikian rupa berat, karena dari segi gangguan keamanan yang dimaksud itu selain ditujukan kepada umum, juga kerapkali mengakibatkan pembunuhan, perampasan, perusakan, dan lainnya. Oleh karena itu, kejahatankejahatan ini oleh siapa pun tidak boleh diberi ampun. Orangorang yang mendapatkan hukuman sebagaimana dimaksud pada ayat ini selain dipandang hina di dunia, mereka di akhirat diancam denga siksaan yang amat pedih. ${ }^{27}$

Jarimah hirabah ini tidak dibutuhkan penjelasan ukuran kerusakan yang menimpa masyarakat. Ia merupakan jarimah yang menakutkan masyarakat (mahkumin), mengganggu pemerintah (hakimin) dan mengabaikan kebaikan-kebaikan yang bersifat manusiawi dan masyarakat. Kemaslahatan menghendaki agar pelakunya diberi hukuman sebagaimana dalam bunyi ayat tersebut, agar mereka berhenti mengganggu keamanan dan berbuat kerusakan dan kejelekan di atas bumi

Berdasarkan al-Maidah (5): 33, sangatlah tepat jika pemerintah Indonesia pernah memberlakukan asas berlaku surut pada tindak pidana terorisme, yang terjadi di Bali pada tahun 2002, yang mengakibat orang yang tidak bersalah terbunuh dan terluka anggota badannya, dengan menerbitkan Perpu 1 dan Perpu 2 walaupun terjadi kritikan dari berbagai kalangan, yang hanya berpikiran asas legalitas. Pada waktu itu belum ada undang-undang tentang terorisme, padahal peristiwanya lebih berat daripada yang ada dalam Kitab Undang-undang Hukum Pidana (KUHP), yang masih berlaku sampai saat ini.

${ }^{27}$ Kemenag RI, A/-Qur'an, 390

\begin{tabular}{l|l}
578 & $\begin{array}{l}\text { al-Daulah } \\
\text { Vol. 5. no.2. Oktober } 2015\end{array}$
\end{tabular} 
Di Indonesia pada tahun 2002 telah diundangkan Perpu Nomor 1 tentang Pemberantasan Tindak Pidana Terorisme dan Perpu Nomor 2 Tahun 2002 tentang Pemberlakuan Perpu Nomor 1 Tahun 2002 terkait dengan peristiwa bom di Bali, yang terjadi pada 12 Oktober 2002. Akhirnya, pada tahun 2003 Perpu ini menjadi Undang-undang Nomor 15 tentang Penetapan Perpu Nomor 1 Tahun 2002 tentang Pemberantasan Tindak Pidana Terorisme. Perpu No. 1 Tahun 2002 diumumkan oleh Menteri Kehakiman dan Ha Asasi Manusia, Yusril Ihza Mahendra, dengan didampingi Menko Polkan, Susilo Bambang Yudhoyono, di Istana Negara pada 18 Oktober 2012 dan diberlakukan secara retroaktif (berlaku surut). Artinya, Perpu tersebut diumumkan pada 18 Oktober 2002, tetapi berlakunya sejak 12 Oktober 2002. Dalam hal ini, Yusril menyatakan, bahwa pemerintah Indonesia telah melakukan langkah-langkah untuk memerangi terorisme.

Berdasarkan beberapa kasus terungkap bahwa terorisme merupakan tindak pidana lintas negara dan dikategorikan kejahatan luar biasa (extra ordinary crime) atau juga disebut sebagai kejahatan terhadap kemanusiaan (crimes against humanity). Dengan adanya peledakan bom di Kutai Bali dan resolusi Dewan Keamanan Perserikatan Bangsa-bangsa, maka unsure kepentingan memaksa yang menjadi persyaratan diterbitkannya Perpu terpenuhi..$^{28}$

Selanjutnya, Yusril menyatakan bahwa ditetapkannya dua Perpu dalam waktu yang sama adalah lazim sebagi wujud kehatihatian pemerintah untuk memberlakukan asas retroaktif. Pada dasarnya, Perpu tidak dapat diberlakukan surut. Akan tetapi, karena korban sangat besar dan terorisme merupakan kejahatan luar biasa sekaligus merupakan kejahatan kemanusiaan, maka demi keadilan dan pertimbangan-pertimbangan lain, perlu diberlakukan surut. Namun pemberlakuan surut itu hanya

${ }^{28}$ Kompas, 19 Oktober 2002, I 
terbatas untuk penyelidikan, penyidikan, dan penuntutan kasus bom di Bali, yang terjadi pada 12 Oktober 2002.

Sedangkan, kasus-kasus peledakan bom lainnya tetap diberlakukan Kitab Undang-undang Hukum Pidana atau Undangundang Nomor 12 Drt Tahun 1951 tentang Senjata Api. Bahkan, Yusril juga menyatakan, bahwa demi keadilan dan pertimbanganpertimbangan lain sebagaimana dimaksud dalam Pasal $28 \mathrm{~J}$ ayat (2) UUD 1945, maka Perpu ini dipadang perlu untuk berlaku surut. Menurut dia, adalah tidak sejalan dengan jiwa dan makna yang termaktub dalam Pasal 28 J ayat (2) UUD 1945 jika para pelaku peristiwa pekedakan bom di Bali dapat menghindar dari tuntutan hukum dengan cara berlindung di balik ketentuan Pasal I ayat (1) UUD 1945.29

Di samping hal tersebut, Yusril menegaskan, bahwa lahirnya Perpu No.1 Tahun 2002 dan Perpu No. 2 Tahun 2002 mengacu pada tiga kepentingan esensial, yaitu perlindungan terhadap korban atau calon korban terorisme, perlindungan terhadap keamanan nasional dan due process of law (perwujudan proses peradilan yang adil). Dalam hal ini, Prija Djatmika mengatakan bahwa pemerintah benar-benar konsisten pada tiga jalur tersebut dalam melaksanakan dua Perpu tersebut, teritama saat Perpu beraksi in concreto bagi tersangkan pelaku terorisme. Artinya, jangan sampai rakyat aman dari teror individu atau organisasi, tetapi ganti menjadi korban teror oleh negara (state terrorism). ${ }^{30}$ Sementara, kelompok lain yang didominasi oleh para aktifis hak asasi manusia, praktisi hukum, lembaga swadaya masyarakat, dan sebagian kalangan perguan tinggi menentang Perlu diberlakukan surut. Misalnya, Indriyanto Seno Adji (pakar hukum pidana UI), sekarang menjadi hakim Tipikor, menyatakan tidak perlu menggunakan Perpu Nomor 1 dan 2 Tahun 2002, tetapi lebih baik memberlakukan rencana undang-undang tentang Penanggulangan Keadaan Bahaya (PKB) atau dengan Pasal 187

${ }^{29} \mathrm{lbid}$

${ }^{30}$ Prija Djatmika, "Terorisme Negara Melalui Perpu", Jawa Pos, 19 Oktober 2002, 4 
dan Pasal 340 KUHP serta UU Nomor 12 Drt 1951 tentang Senjata Api. ${ }^{31}$

Berdasarkan pernyataan Yusril sebagai wakil pemerintah dan kelompok yang menentang pemerintah tentang pemberlakuan surut Perpu Nomor 1 dan 2 Tahun 2002, maka syari'at Islam telah memberlakukan asas legalitas, sebelum adanya Pasal 1 ayat (1) KUHP yang merupakan produk Belanda, yang masih berlaku sampai sekarang berdasarkan aturan peralihan UUD 1945. Akan tetapi, syari'at Islam pernah juga memberlakukan asas retroaktif terhadap kasus-kasus yang benar-benar berbahaya dan mengganggu keamanan dan ketertiban umum, yaitu hirabah, qadhaf, dan zihar. Sangatlah tepat sekali jika terorisme ini dimasukkan dalam tindak pidana hirabah dalam surat al-Maidah (5): 33, sebagaimana hasil Ijtima' Ulama Jakarta, pada tanggal 1416 Desember 2003.32Dengan demikian, kedua asas, legalitas dan retroaktif, dipakai dalam hukum Islam.

Dalam alasan pertimbangan Perpu Nomor 2 Tahun 2002 ditegaskan: (a) bahwa dalam rangka mencegah dan memberantas tindak pidana terorisme, Presiden Republik Indonesia telah menetapkan Perpu No. 1 Tahun 2002 tentang Pemberantasan Tindak Pidana Terorisme; (b) bahwa peristiwa pemboman yang terjadi di Bali pada tanggal 12 Oktober 2002 telah menimbulkan suasana terror atau rasa takut terhadap orang secara meluas serta mengakibatkan hilangnya nyawa dan harta benda orang lain; (c) bahwa berdasarkan pertimbangan sebagaimana dimaksud dalam huruf a dan hiruf $b$, perlu menetapkan Perpu tentang Pemberlakuan Perpu Nomor 1 Tahun 2002 tentang Pemberantasan Tindak Pidana Terorisme, pada Peristiwa Peledakan Bom di Bali tanggal 12 Oktober 2002.

Selanjutnya, Pasal 1 Perpu Nomor 2 Tahun 2002 menyebutkan: Ketentuan dalam Peraturan Pemerintah Pengganti Undang-undang Nomr 1 Tahun 2002 tentang Pemberantasan

${ }^{31}$ Kompas, 20 Oktober 2002, I

32 Makhrus Munajat, Dekonstruksi Hukum Pidana Islam, 120 
Tindak Pidana Terorisme, dinyatakan berlaku terhadap peristiwa peledakan bom yang terjadi di Bali pada tanggal 12 Oktober 2002. Sementara itu, Perpu No. 2 Tahun 2002 ditetapkan pada tanggal 18 Oktober 2002. Dengan demikian, walapun ditetapkan pada 18 Oktober 2002, tetapi berlakunya sejak 12 Oktober 2002, sehingga peristiwa bom Bali diterapkan Perpu No. 1 Tahun 2002, yang diberlakusurutkan.

Kenyataan tersebut menunjukkan peristiwa-peristiwa yang sebelum turun al-Qur'an, kemudian peristiwa tersebut sebagai peyebab turunnya al-Qur'an, yang ketentuan hukumnya diperuntukkan untuk menghukum terhadap orang-orang yang melakukan tindakan sebelum al-Qur'an diturunkan. Hal ini sesuai dengan kaidah dalam Ulum al-Qur'an, al-ibrah bi khusus al-sabab la bi 'umum al-lafz (pemahaman teks berdasarkan atas sebab yang khusus, bukan berdasarkan atas keumuman lafal) dan ini merupakan salah satu kegunaan mempelajari sabab al-nuzul, yakni mentakhsis ketentuan umum yang terdapat dalam nas alQur'an. ${ }^{33}$ Untuk itu, penerapan teori al-'ibrah bi khusus al-sabab ini sama dengan pemberlakuan surut dalam kasus peledakan bom di Bali, yang terjadi pada tanggal 12 Oktober 2002, padahal Perpu Nomor 1 dan 2 Tahun 2002 diumumkan oleh Pemerintah pada tanggal 18 Oktober 2002.

Walaupun asas legalitas dalam syari'at Islam telah diatur dalam surat al-Isra' (18): 15 dan al-Qasas (28): 59, tetapi dalam penerapannya ada perkecualian dengan teori takhsis. Dalam hal ini ayat tersebut ditakhsis dengan al-Maidah (5): 35 (hirabah); al-Nur (24): 4 (qadhaf); dan al-Mujadalah (58): 1-3 (zihar). Sementara itu, Abd al-Qadir Awdah menyatakan bahwa riwayat tentang sabab alnuzul surat al-Maidah (5): 33 dan al-Nur (24): 4 terjadi perbedaan pendapat di kalangan ulama, sedangkan al-Mujadalah (58): 1-3 tidak ada. Akan tetapi, terlepas dari perbedaan tersebut versi riwayat tentang sabab al-nuzul ayat tersebut, yang jelas bahwa ayat

${ }^{33}$ Manna' al-Qattan, Mabahith fi 'Ulum al-Qur'an, (Riyad: Manshurat al-'Asr al-Hadith, 1973), 79

\begin{tabular}{l|l}
582 & al-Daulah \\
Vol. 5. no.2. Oktober 2015
\end{tabular} 
al-Qur'an diturunkan untuk memberi ketentuan hukum terhadap peristiwa yang terjadi sebelum diturunkan al-Qur'an. ${ }^{34}$

Berdasar atas teori takhsis 'am al-Qur'an dengan al-Qur'an, maka tidak perbedaan antara mayoritas Shafi'iyyah dan Hanafiyyah tentang kebolehan takhsis. Dengan demikian, berlakulah kaidah, ma min 'am illa wa fih al-takhsis (tidak ada lafal umum, kecuali ada pengecualinnya/pembarasnya) atau lex specialis derogate legi generali (ketentuan hukum khusus dapat mengenyampingkan yang umum).

Dengan demikian, pemberlakuan surut Perpu No. 1 melalui Perpu No. 2 Tahun 2002, yang sekarang telah menjadi UU No. 15 Tahun 2003 dapat dibenarkan walaupun pada mulanya asas hukum pidana tidak memberlakukannya. Hal ini didasarkan bahwa bahwa asas hukum itu bersifat umum dan abstrak. Oleh karena itu, membuka kemungkinan-kemungkinan terjadinya penyimpangan, sehingga sisitem hukum itu menjadi luwes dan tidak kaku. Dalam hal ini, asas retroaktif dalam Perpu, yang terkait dengan bom Bali sama atau hampir sama dengan materi yang ada dalam ayat hirabah. Hal demikian sejalan dengan pemikian Ali alSabuni dalam Rawa'i al-Bayan setelah mengemukakan pendapat ulama tentang "muharib", kemudian dia mendapat yang lebih kuat (arjah), bahwa muharib terkadang berupa kelompok yang berada di tengah-tengah masyarakat, yang menakut-manuki mereka, baik jiwa maupun harta, yang lebih berat daripada pembegal (penyamun) di tengah jalan yang sunyi dari kerumunan orang. ${ }^{35}$

Oleh karena itu, pelaku peledakan bom di Kutai Bali dapat dimasukkan dalam kategori muharib, yang ayatnya digunakan asas berlaku surut dengan menggunakan teori dalalat al-nas (Hanafiyyah) atau mafhum muwafaqah (Shafi'iyyah). Bahkan, jika melihat korbannya, maka korban yang terjadi di Kutai Bali itu lebih banyak daripada yang terjadi berdasarkan sabab al-nuzul,

\footnotetext{
${ }^{34}$ Abd al-Qadir, al-Tashri, 284-285.

${ }^{35}$ Ali al-Sabuni, Rawa'i al-Bayan Tafsir Ayat al-Ahkam min al-Qur'an, vol. I, (Beirut: Dar al-Fikr, t.t), 552
} 
sehingga dapat dimasukkan dalam tingkatan fahwa al-khitab atau qiyas awla dalam teori qiyas (analogi).

Sementara itu, jika dilihat dari maqasid al-shari'ah, maka pemberlakuan berlaku surut pada muharib, termasuk pelaku bom Bali adalah dalam upaya menjaga jiwa dan harta, yang bersifat daruriyyah (primer).

Pemberlakuan surut Perpu Nomor 1 Tahun 2002 oleh pemerintah Indonesia merupakan tindakan freies ermessen atau pouvoir diecretionnaire. Artinya, pemerintah tidak perlu mendasari secara ketat terhadap norma-norma yang terdapat dalam undangundang, tetapi harus segera dapat bertindak berdasarkan keperluan untuk mengatasi situasi mendadak dan sebagainya selama tidak melampaui batas kewenangan dan hukum. ${ }^{36}$ Dalam hal ini, pemerintah bertindak demi kepentingan umum, kepentingan bangsa, dan negara, sebagaimana tertuang dalam kaidah fiqh, tasarruf al-imam 'ala al-ra'iyyah manut bi al-maslahah ${ }^{37}$ (kebijakan pemerintah terhadap rakyatnya harus dikaitkan dengan kepentingan umum).

Berdasarkan pendekatan sabab al-nuzul, dengan menggunakan kaidah "al-'ibrah bi khusus al-sabab la bi 'umum al-lafz", bukan "'al'ibrah bi 'umum al-lafzi la bi khusus al-sabab", asas rekroaktif dalam hukum pidana Islam lebih luas, tidak hanya kepentingan pelaku yang menguntungkan, sebagaimana dalam Pasal 1 ayat (2) KUHP, tetapi juga diterapkan dalam tindak pidana yang mengganggu kepentingan umum, rakyat, bangsa dan negara. Penerapan ini yang dijadikan alasan pertimbangan oleh Yusril dalam memberlakukan surut Perpu No. 1 tahun 2002 terkait terorisme walaupun ditentang oleh kelompok lain, yang bukan pemerintah.

36 Kuntjoro Purbopranoto, Beberapa Catatan Hukum Tata Pemerintahan dan Peradilan Adminstrasi Negara, (Bandung: Penerbit Alumni, 1981), 44; C.S.T Kansil, Hukum Tata Pemerintahan Indonesia, (Jakarta: Ghalia Indoneia, 1984), 21

${ }^{37}$ al-Suyuti, al-Ashbah wa al-Nazair, (Mesir: Matba'at al-Mustafa Muhammad, t.t), 108 


\section{Penutup}

Manfaat sabab al-nuzul terkait dengan ayat hukum, yaitu (a) dapat diketahui hikmah dan rahasia diundangkannya suatu hukum dan perhatian shara' terhadap kepentingan umum; (b) dapat membantu memberikan kejelasan terhadap beberapa ayat hukum; (c) dapat mengkhususkan hukum terbatas pada lafal umum, terutama ulama yang menggunakan kaidah khusus al-sabab, bukan 'umum al-lafz; (d) dapat membantu memahami apakah suatu ayat itu berlaku umum atau khusus, kemudian dalam hal apa ayat itu diterapkan; (e) dapat memudahkan orang menghafal ayat-ayat al-Qur'an serta memperkuat keberadaan wahyu dalam ingatan orang yang mendengarnya jika mengetahui sebab turunnya.

Dampak sabab al-nuzul terhadap penerapan asas berlaku surut (athar raj'i), yaitu hukum yang diturunkan akan diberlakukan sejak peristiwa hukum (tindak pidana) itu terjadi, bukan sejak al-Qur'an diturunkan, menurut kaidah sabab al-nuzul, al-'ibrah bi khusus alsabab, bukan al-'ibrah bi 'umum al-lafz, terkait dengan tindak pidana yang mengganggu masyarakat atau kepentingan umum, seperti muharabah dalam al-Maidah (5): 33 atau tindak pidana terorisme dengan lahirnya Perpu Nomor 1 dan 2 Tahun 2002, yang kemudian menjadi UU Nomor 15 Tahun 2003.

\section{Daftar Pustaka}

'Awwa (al-), Muhammad Salim. Fi Usul al-Nizam al-Jinai al-Islami. Kairo: Dar al-Ma'arif, 1979.

Ashshafa, Burhan. Metode Penelitian Hukum. Jakarta: PT Makasaty, 2001.

Asikin, Zainal. Pengantar Ilmu Hukum. Jakarta: Raja Grafindo Persada, 2012.

Awdah, Abd al-Qadir. al-Tashri' al-JinaI al-Islami Muwazanah bi alQanun al-Wad'i. Vol. 1, Beirut: Dar al-Kutub al-'Arabi, t.t. Bukhari (al-). Sahih al-Bukhari. Vol. IV, Beirut: Dar al-Fikr, t.t. 
Depag. Al-Quran dan Terjemahnya. Jakarta: Proyek Pengadaan Kitab Suci al-Quran, 1983.

Djatmika, Prija. "Terorisme Negara Melalui Perpu", Jawa Pos, 19 Oktober 2002.

Hawwa, Sa'id. al-Islam. Vol. 4. Beirut: Dar al-Qalam, t.t.

Hadisoeprapto, Hartono. Pengantar Tata Hukum Indonesia. Yogyakarta: Libery, 2000.

Hamzah, Andi. Kampus Hukum. Jakarta: Ghallia Indonesia, 1986.

Hanafi, A. Asas-Asas Hukum Pidana Islam. Jakarta: Bulan Bintang, 1976.

Kansil, C.S.T. Hukum Tata Pemerintahan Indonesia. Jakarta: Ghalia Indoneia, 1984.

Kathir, Ibn. Tafsir al-Qur'an al-'Azim. Vol. 3, Mesir: 'Isa al-Babi alHalibi, t.t.

Kementrian Agama RI. Al-Qur'an dan Tafsirnya. Vol. 2, Jakarta:

Sinergi Pustaka Indonesia, 2012.

Kompas, 19 dan 20 Oktober 2002

Mudjiono. Sistem Hukum dan Tata Hukum Indonesia. Yogyakarta: Liberty, 2000.

Munajat, Makhrus. Dekonstruksi Hukum Pidana Islam. Sleman: Logung Pustaka, 2004.

Purbopranoto, Kuntjoro. Beberapa Catatan Hukum Tata Pemerintahan dan Peradilan Adminstrasi Negara. Bandung: Penerbit Alumni, 1981.

Qattan (al-), Manna'. Mabahith fi 'Ulum al-Qur'an. Beirut: Dar alQalam li al-Malayin, 1988.

-------. Mabahith fi 'Ulum al-Qur'an. Riyad: Manshurat al-'Asr alHadith, 1973.

Sabuni (al-), Muhammad Ali. al-Tibyan fi 'Ulum al-Qur'an. Damaskus: Maktabat al-Ghazali, $1390 \mathrm{H}$.

-. Rawa'i al-Bayan Tafsir Ayat al-Ahkam min al-Qur'an. Vol. 1, Beirut: Dar al-Fikr, t.t.

Sabiq, al-Sayyid. Fiqh al-Sunnah. Vol. 2, Beirut: Dar al-Fikr, 1977.

Shihab, M. Quraish. Membumikan al-Qur'an. Bandung: Mizan, 1992. 
, et.al, Sejarah dan Ulumul Qur'an. Jakarta: Pustaka Firdaus, 1999.

Susilo, R. Kitab Undang-Undang Hukum Pidana (KUHP) Serta Komentar-Komentar Lengkap Pasal-Pasal. Bogor: Politeia, 1976.

Suyuti (al-). al-Ashbah wa al-Nazair. Mesir: Matba'at al-Mustafa Muhammad, t.t.

Syadali, Ahmadi dan Ahmad Rofi'i. Ulumul Quran. Bandung: Pustaka Setia, 1997.

Syarifin, Pipin. Pengantar Ilmu Hukum. Bandung: Pustaka Setia, 1999.

. Hukum Pidana di Indonesia. Bandung: Pustaka Setia. 2000.

Tongat. Dasar-dasar Hukum Pidana Indonesia dalam Perspektif Pembaharuan. Malang: UMM Press, 2008.

Zahrah, Muhammad Abu. al-'Uqubah. Mesir: Dar al-Fikr al-'Arabi, 1999. 